\title{
Meningkatkan Hasil Belajar Logika Pada Mata Pelajaran Matematika Menggunakan Metode Sosiodrama
}

\author{
Author: \\ Adhy Winaktu ${ }^{1}$ \\ Supardi U.S \\ Afiliation: \\ Universitas Indraprasta \\ PGRI \\ Corresponding email \\ winaktuadhy@gmail.com \\ Histori Naskah: \\ Submit: 2021-11-17 \\ Accepted: 2021-11-24 \\ Published: 2021-12-01 \\ This is an Creative Commons \\ License This work is licensed \\ under a Creative Commons \\ Attribution-NonCommercial 4.0 \\ International License
}

Abstrak:

Penelitian ini beranjak dari fenomena yang terjadi di kelas bahwa rendahnya pemahaman dan hasil belajar peserta didik pada mata pelajaran Matematika tentang logika matematika. Oleh karena itu seorang guru perlu mempertimbangkan strategi pembelajaran sehingga dapat meningkatkan hasil belajar peserta didik. Penelitian ini bertujuan (1) Untuk mengetahui metode sosiodrama dapat meningkatkan hasil belajar peserta didik pada mata pelajaran Matematika tentang logika Matematika di Kelas XI IPA 3 SMAN 34 Pondok Labu Jakarta semester 1 tahun pelajaran 2021/2022. (2) Untuk menggambarkan proses peningkatan hasil belajar peserta didik pada mata pelajaran Matematika tentang logika Matematika di Kelas XI IPA 3 SMAN 34 Pondok Labu Jakarta semester 1 tahun pelajaran 2021/2022. (3) Untuk mengukur besarnya peningkatan hasil belajar peserta didik pada mata pelajaran Matematika tentang logika Matematika setelah menggunakan Metode sosiodrama di Kelas XI IPA 3 SMAN 34 Pondok Labu Jakarta semester 1 tahun pelajaran 2021/2022.

Hasil penelitian ini menunjukkan bahwa dengan menggunakan metode sosiodrama dapat menjadi variasi pembelajaran yang menyenangkan bagi peserta didik sehingga terbukti meningkatkan hasil belajar peserta didik di Kelas XI IPA 3 SMAN 34 Pondok Labu Jakarta. Sebelum menggunakan metode pemberian tugas hasil belajar peserta didik hanya mencapai nilai rata-rata 62,87 kemudian terjadi peningkatan setelah menggunakan metode pemberian tugas menjadi 71,25 pada siklus 1 dan 78,12 pada siklus 2.

Dari uraian di atas peneliti menyimpulkan bahwa penggunaan metode sosiodrama menyenangkan sehingga terjadi peningkatan hasil belajar peserta didik. Oleh karena itu peneliti menyarankan agar penggunaan metode sosiodrama disosialisasikan dan digunakan sebagai alternatif dalam pembelajaran mata pelajaran Matematika di sekolah-sekolah di lingkungan Dinas Pendidikan Jakarta.

Kata kunci: Hasil Belajar, Logika Matematika, Sosiodrama 


\section{Pendahuluan}

Dalam keseluruhan proses pendidikan di sekolah, kegiatan belajar merupakan kegiatan yang paling pokok. Ini berarti tujuan pendidikan dan pembelajaran hanya bergantung kepada bagaimana proses belajar mengajar yang dialami oleh peserta didik. Belajar sendiri adalah suatu proses perubahan yaitu perubahan tingkah laku sebagai hasil dari interaksi dengan lingkungannya dalam memenuhi kebutuhan hidupnya.

Suatu proses belajar dapat dikatakan efektif jika peserta didik dapat belajar secara aktif dan memperoleh pengalaman serta pemahaman dari hasil belajarnya. Masalah pertama dalam proses pembelajaran adalah "Bagaimana seorang guru mengajarkan bahan-bahan kajian sehingga peserta didik memperoleh pemahaman. Oleh karena itu seorang guru harus mampu mendesain dan membuat perencanaan pembelajaran dengan baik.

Mendesain suatu pembelajaran di SMA untuk keperluan proses pembelajaran, tentu bukanlah pekerjaan yang sederhana. Untuk menghasilkan desain pembelajaran, seorang guru harus menguasai materi (content) dan metode pembelajaran (teaching method) agar dapat meningkatkan kualitas belajar mengajar, baik dari segi proses maupun hasil belajar.

Guru yang profesional dituntut untuk mempersiapkan peserta didik yang awalnya belum siap menuju kesiapan dan kematangan diri. Kematangan pribadi peserta didik tercermin dalam pada tiga hal, yaitu aspek kognitif (pengetahuan), afektif (sikap), dan psikomotor (keterampilan). Persiapan menuju kematangan tersebut dilaksanakan dalam proses pendidikan yang sistematis, berkesinambungan dan berjenjang.

Hal ini berbanding balik dengan kenyataan di lapangan, masih banyak guru yang masih berani masuk ke dalam kelasnya tanpa membuat perencanaan yang baik, tidak menggunakan media dan metode yang tepat serta guru menyajikan pelajaran hanya sebatas apa adanya dalam buku teks. Guru terkesan hanya mementingkan hasil belajar peserta didik tanpa mengedepankan proses belajar itu sendiri.

Hal ini dialami oleh penulis pada pembelajaran Matematika tentang logika Matematika di kelas XI IPA 3 SMAN 34 Pondok Labu Jakarta Dari 40 peserta didik hanya 12 peserta didik atau 30\% yang mendapat nilai di atas KKM sedangkan 28 peserta didik atau 70\% masih mendapat nilai di bawah KKM dengan rata rata nilai 62,87 sedangkan nilai KKM yang diharapkan 70 . Kesimpulan awal penulis pada pembelajaran adalah media dan metode yang digunakan belum menyentuh kebutuhan peserta didik sehingga hasil belajar tidak sesuai dengan apa yang diharapkan.

Pembelajaran matematika adalah proses pemberian pengalaman belajar kepada peserta didik melalui serangkaian kegiatan terencana sehingga peserta didik memperoleh kompetensi tentang bahan matematika yang dipelajari (Muhsetyo, 2009:1.26). Hudoyo (dalam Meisera 2013) menyatakan "seseorang dikatakan belajar matematika apabila pada diri orang tersebut terjadi suatu kegiatan yang dapat mengakibatkan perubahan tingkah laku yang berkaitan dengan matematika“"

Atas dasar itulah penulis melakukan upaya perbaikan pembelajaran dengan menggunakan metode sosiodrama karena metode ini menurut Zainal Aqib (2016: 183) menyatakan "metode sosiodrama yang merupakan metode mengajar dengan cara mempertunjukkan kepada peserta didik tentang masalah-masalah hubungan sosial, untuk mencapai tujuan pengajaran tertentu. Masalah hubungan sosial tersebut didramatisasikan oleh peserta didik di bawah pimpinan pendidik, melalui metide ini, pendidik ingin mengajarkan cara-cara tingkah laku dalam hubungan antara sesama manusia."

Belajar matematika tidak sekedar untuk mengetahui tetapi juga belajar melakukan, belajar menjiwai, belajar bagaimana belajar, serta belajar bersosialisasi dengan sesama teman (Ariani dan Widiastuti, 2010:2). Dalam pembelajaran ada bermacam-macam model pembelajaran yang dapat digunakan guru di kelas agar siswa 
lebih tertarik terhadap matematika. Menurut Joyce \& Weil (dalam Rusman, 2010:133) model-model pembelajaran biasanya disusun berdasarkan prinsip atau teori pengetahuan. Para ahli menyusun model pembelajaran berdasarkan prinsip-prinsip pembelajaran, teori-teori psikologis, sosiologis, analisis sistem, atau teori-teori lain yang mendukung.

Dari uraian di atas maka penulis menentukan judul penelitian tindakan kelas ini adalah Meningkatkan Hasil Belajar Logika Pada Mata Pelajaran Matematika Menggunakan Metode Sosiodrama di Kelas XI IPA 3 SMAN 34 Pondok Labu Jakarta Semester 1 Tahun Pelajaran 2021/2022

\section{Studi Literatur}

Dalam melakukan penelitian ini, peneliti juga melakukan riset terhadap beberapa penelitian sebelumnya diantaranya yaitu penelitian dari Okta Rina Wahyuni (2014:88-99) dalam penelitian yang berjudul Upaya Peningkatan Prestasi Belajar Siswa Pada Kompetensi Dasar Aritmatika Sosial Dengan Model Pembelajaran Bermain Peran menyatakan bahwa prestasi belajar siswa kelas VII SMPN 4 Satu Atap Konang tahun pelajaran 2013/2014 dengan model pembelajaran bermain peran pada kompetensi dasar aritmatika sosial mengalami peningkatan. Sebelum dilakukan kegiatan siklus I dan siklus II, peneliti melakukan kegiatan prasiklus untuk mengetahui prestasi belajar siswa sebelum diberi tindakan.

Erma Yulita (2021:1-14) juga melakukan penelitian tentang Penerapan Pendekatan Realistic Mathematics Education Untuk Meningkatkan Hasil Belajar Matematika Pada Siswa Kelas III.B Madrasah Ibtidaiyah Negeri Tembilahan Kecamatan Tembilahan menyatakan bahwa penerapan pendekatan realistic mathematics education dapat meningkatkan hasil belajar Matematika pada siswa kelas III.B Madrasah Ibtidaiyah Negeri Tembilahan Kecamatan Tembilahan Hulu, yaitu aktivitas guru pada siklus I adalah 26 $(47,27 \%)$, pada siklus II mengalami peningkatan menjadi 42 (76,36\%). Aktivitas siswa pada siklus I adalah $132,33(60,81 \%)$, pada siklus II mengalami peningkatan menjadi 192,67 (87,57\%). Ketuntasan hasil belajar siswa pada siklus I rata-rata 79,5 dan 12 orang siswa $(60 \%)$ telah tuntas. Pada siklus II mengalami peningkatan menjadi 1679 dengan ratarata 83,95 dan 20 orang siswa (100\%) tuntas.

Dari beberapa penelitian di atas penulis masih belum menemukan penelitian yang sesuai dengan penelitian yang akan dilakukan. Penelitian ini akan dilakukan guna meningkatkan hasil belajar logika pada mata pelajaran Matematika menggunakan metode sosiodrama.

Sosiadrama adalah metode pembelajaran bermain peran untuk memecahkan masalah-masalah yang berkaitan dengan fenomena sosial, permasalahan yang menyangkut hubungan antara manusia seperti masalah kenakalan remaja, narkoba, gambaran keluarga yang otoriter, dan lain sebagainya. Sosiodrama digunakan untuk memberikan pemahaman dan penghayatan akan masalah-masalah sosial serta mengembangkan kemampuan peserta didik untuk memecahkannya. Adapun menurut winkel (2008) sosiodrama merupakan dramatisasi dari berbagai persoalan yang dapat timbul dalam pergaulan dengan orang lain, termasuk konflik yang sering dialami dalam pergaulan sosial. Sedangkan menurut Wiryaman (200:1-27) bahwa metode sosiodrama merupakan metode mengajar dengan mempertunjukkan kepada peserta didik tentang masalah-masalah. Hal tersebut dilakukan dengan menunjukkan kepada peserta didik masalah bimbingan hubungan sosial tersebut didramatisir oleh peserta didik di bawah pimpinan pendidik.

Sementara itu menurut Djamarah (2007:200) berpendapat bahwa metode sosiodrama adalah cara mengajar yang memberikan kesempatan peserta didik untuk melakukan kegiatan memainkan peran tertentu yang terdapat dalam kehidupan masyarakat. Kemudian menurut kamus Besar Bahasa Indonesia, sosiodrama adalah drama yang bertujuan memberikan informasi kepada masyarakat tentang masalah sosial dan politik. 
Edu Cendikia: Jurnal Ilmiah Kependidikan

Volume: 1 | Nomor 3 | Desember 2021 | E-ISSN: 2798-365X | DOI: 10.47709/educendikia.v1i3.1175

Dari pengertian-pengertian di atas dapat disimpulkan bahwa metode sosiadarama adalah metode pembelajaran sosiodrama adalah model pembelajaran bermain peran dengan mendramatisasi kehidupan nyata atau konflik yang belum terselesaikan dan sistem sosial yang membentuk kita secara individu dan kolektif.

Tujuan metode sosiodrama adalah sebagai berikut:

a. Agar anak didik mendapatkan keterampilan sosial sehingga diharapkan nantinya tidak canggung menghadapi situasi sosial dalam kehidupan sehari-hari.

b. Menghilangkan perasaan kurang percaya diri dan rendah diri yang tidak pada tempatnya.

c. Mendidik dan mengembangkan kemampuan dan untuk mengemukakan pendapat didepan teman sendiri atau orang lain.

d. Membiasakan diri untuk sanggup menerima dan menghargai pendapat orang lain.

Metode drama wajar digunakan dalam rangka mencapai tujuan-tujuan yang mengandung sifat-sifat sebagai berikut:

a. Memahami perasaan orang lain

b. Membagi pertanggungan jawab dan memikulnya

c. Menghargai pendapat orang lain

d. Mengambil keputusan dalam kelompok

e. Memperbaiki hubungan sosial

f. Mengenali nilai-nilai dan sikap-sikap

g. Menanggulangi atau memperbaiki sikap-sikap salah

Hasil Belajar

Prestasi belajar dapat diartikan sebagai hasil maksimum yang telah dicapai oleh peserta didik setelah mengalami proses belajar mengajar dalam mempelajari materi pelajaran tertentu. Hasil belajar tidak mutlak berupa nilai saja, akan tetapi dapat pula berupa perubahan atau peningkatan sikap, kebiasaan, pengetahuan, keuletan, ketabahan, penalaran, kedisiplinan, keterampilan dan sebagainya yang menuju pada perubahan positif.

Ada lima kelompok kemampuan peserta didik sebagai hasil belajar yaitu:

a. Keterampilan Intelektual (intelektual skills)

b. Kemampuan mengenal, memahami, dan menggunakan suatu konsep masalah Strategi Kognitif (attitudes)

c. Kemampuan memilih dan mengubah cara-cara memberikan perhatian belajar, mengingat, dan berpikir Informasi Verbal (verbal skills)

d. Kemampuan menyimpan nama/label, fakta, pengetahuan dalam ingatan

e. Keterampilan Motorik (motor information) 
Edu Cendikia: Jurnal Ilmiah Kependidikan

Volume: 1 | Nomor 3 | Desember 2021 | E-ISSN: 2798-365X | DOI: 10.47709/educendikia.v1i3.1175

f. Kemampuan melakukan kegiatan secara fisik yang dibarengi dengan keterampilan intelektual

g. Sikap/kognitif (cognitive strategies)

h. Kemampuan berfikir positif dan menampilkan perilaku yang bermuatan nilai-nilai luhur.

Pembelajaran Tentang Logika Matematika

Apa itu logika matematika? Penjelasan singkatnya, logika matematika adalah aturan berpikir atau landasan tentang bagaimana cara kita mengambil kesimpulan. Pertimbangan akal pikiran yang kita gunakan untuk menarik kesimpulan bukan hanya didasarkan pada logika alamiah, namun juga logika ilmiah.

\section{Pengertian Proposisi}

Logika matematika sangat dekat kaitannya dengna pernyataan dan penarikan kesimpulan. Itulah sebabnya saat belajar materi ini siswa harus paham dengan proposisi. Proposisi adalah suatu pernyataan yang mempunyai dua kemungkinan nilai kebenaran, yaitu benar atau salah tetapi tidak munbgkin keduanya (lebih dari satu).

Contohnya, angka 2 adalah bilangan genap merupakan pernyataan benar. Bilangan genap merupakan bilangan bulat dan habis dibagi 2. Angka 2 termasuk bilangan bulat dan akan habis jika dibagi 2 .

Proposisi pada logika matematika terbagi menjadi 3 jenis, yaitu proposisi tunggal, majemuk, dan kompleks. Jenis proposisi tunggal yaitu pernyataan tanpa perangkai. Sementara proposisi majuemuk memiliki satu perangkai. Terakhir proposisi kompleks memiliki dua atau lebih perangkai.

\section{Perangkai Dasar Proposisi}

Ada 5 perangkai dasar proposisi dalam logika matematika, antara lain ingkaran atau negasi, konjungsi, disjungsi, implikasi, dan biimplikasi. Untuk menarik suatu kesimpulan yang benar dari suatu proposisi, sisiwa harus memahami terlebih dahulu setiap perangkai dasarnya.

Teori dasar mengenai Logika matematika sebagai berikut:

\section{KONVERS, INVERS, KONTRAPOSISI}

Dari pernyataan implikasi : $\mathrm{p} \rightarrow \mathrm{q}$ maka bentuk:

\begin{tabular}{|c|c|c|c|}
\hline Implikasi & Invers & Konvers & Kontraposisi \\
\hline $\mathrm{p} \Rightarrow \mathrm{q}$ & $\sim \mathrm{p} \Rightarrow \sim \mathrm{q}$ & $\mathrm{q} \Rightarrow \mathrm{p}$ & $\sim \mathrm{q} \Rightarrow \sim \mathrm{p}$ \\
\hline
\end{tabular}

\section{II.EQUIVALENSI}

Adalah Pernyataan yang senilai atau pernyataan yang memiliki kesetaraan atau pernyataan yang mempunyai nilai tabel kebenaran yang sama. Symbol “ ””.

Pernyataan yang equivalen:

$$
\text { Implikasi } \equiv \text { kontraposisi } \quad: \mathrm{p} \rightarrow \mathrm{q} \equiv \sim \mathrm{q} \rightarrow \sim \mathrm{p}
$$


Edu Cendikia: Jurnal Ilmiah Kependidikan

Volume: 1 | Nomor 3 | Desember 2021 | E-ISSN: 2798-365X | DOI: 10.47709/educendikia.vli3.1175

$$
\begin{aligned}
& \text { Konvers } \equiv \text { invers } \quad: q \rightarrow p \equiv \sim p \rightarrow \sim q \\
& p \rightarrow q \equiv \sim p \vee q
\end{aligned}
$$

III. NEGASI PERNYATAAN

\begin{tabular}{|l|l|}
\hline \multicolumn{1}{|c|}{ Pernyataan } & \multicolumn{1}{c|}{ Negasi } \\
\hline $\mathrm{p} \wedge \mathrm{q}$ & $\sim(\mathrm{p} \wedge \mathrm{q})=\sim \mathrm{p} \vee \sim \mathrm{q}$ \\
$\mathrm{p} \vee \mathrm{q}$ & $\sim(\mathrm{p} \vee \mathrm{q})=\sim \mathrm{p} \wedge \sim \mathrm{q}$ \\
$\mathrm{p} \rightarrow \mathrm{q}$ & $\sim(\mathrm{p} \rightarrow \mathrm{q})=\mathrm{p} \wedge \sim \mathrm{q}$ \\
$\mathrm{p} \leftrightarrow \mathrm{q}$ & $(\mathrm{p} \wedge \sim \mathrm{q}) \vee(\mathrm{q} \wedge \sim \mathrm{p})$ \\
semua yang $\mathrm{p}(\mathrm{x})$ & ada yang tidak $\mathrm{p}(\mathrm{x})$ \\
ada yang $\mathrm{p}(\mathrm{x})$ & semua yang tidak $\mathrm{p}(\mathrm{x})$ \\
\hline
\end{tabular}

\section{PENARIKAN KESIMPULAN}

* Modus Ponen :

Premis umum: $\mathrm{p} \rightarrow \mathrm{q}(\mathrm{B})$

Premis khusus: $p$

$$
\text { Kesimpula } \overline{: q \quad(B)}
$$

* Modus Tollens:

Premis umum: $\mathrm{p} \rightarrow \mathrm{q}$ (B)

Premis khusus: $\quad \sim \mathrm{q}(\mathrm{B})$

Kesimpulan : $\overline{\sim p(B)}$

- Prinsip Sillogisma:

$$
\begin{aligned}
& : p \rightarrow q \\
& : q \rightarrow r
\end{aligned}
$$

Kesimpulan $\overline{\mathrm{p} p \rightarrow \mathrm{r}}$

\section{Metode Penelitian}

Metode penelitiaan yang digunakan dalam penelitian ini adalah deskriptif analitik melalui panelitian tindakan kelas yaitu studi yang digunakan untuk mengumpulkan data, mendeskripsikan, mengolah, menganalisa, menyimpulkan dan menafsirkan data sehingga memperoleh gambaran yang sistematis. Metode penelitian deskriftif analisis digunakan untuk mengetahui permasalahan dengan cara menguraikan secara rinci dan jelas, serta melakukan suatu analisis data dari permasalahan untuk memperoleh suatu 
Edu Cendikia: Jurnal Ilmiah Kependidikan

Volume: 1 | Nomor 3 | Desember 2021 | E-ISSN: 2798-365X | DOI: 10.47709/educendikia.vli3.1175

kesimpulan dengan tujuan untuk mengambarkan dan menganalisis secara sistematis terhadap suatu fakta yang bersifat faktual.

Tempat penelitian pembelajaran berlokasi di SMA Negeri 1 Tajurhalang Kabupaten Bogor. Subjek penelitiannya adalah peserta didik kelas XI IPA 3 semester 1 SMAN 34 Pondok Labu Jakartatahun pelaajaran 2021/2022. Ketika guru mengajar tentang Logika Matematika pada pelajaran Matematika dari 40 peserta didik hanya 12 peserta didik atau 30\% yang mendapat nilai di atas KKM sedangkan 28 peserta didik atau 70\% masih mendapat nilai di bawah KKM dengan rata rata nilai 62,87 sedangkan nilai KKM yang diharapkan 70. Padahal Logika Matematika dirasakan oleh guru sangat penting untuk dipahami oleh peseta didik, jika kondisi pembelajaran ini tidak dapat di atasi maka tujuan pembelajaran tidak tercapai.

Perbaikan pembelajaran ini dilaksanakan selama 6 bulan yaitu dari bulan Januari sampai dengan bulan Juni 2017 yang terdiri dari Pra siklus, Siklus I, dan Siklus II. Adapun mata pelajaran yang menjadi fokus perbaikan adalah Matematika tentang Logika Matematika.

\section{Hasil}

Sebelum melakukan tindakan dalam penelitian peneliti melakukan observasi awal di kelas XI IPA 3 SMA Negeri 1 Tajurhalang Kabupaten Bogor. Hasil observasi menunjukkan bahwa hasil belajar peseta didik mata pelajaran Matematika masih tergolong sangat rendah. Berdasarkan hal tersebut peneliti mencoba menggunakan Metode sosiodrama dalam proses pembelajaran Matematika tentang Logika Matematika. Pembelajaran dimulai dengan mengadakan tes awal (prasiklus) di kelas XI IPA 3 SMAN 34 Pondok Labu Jakartauntuk mengetahui kemampuan awal peserta didik pada mata pelajaran Matematika tentang Logika Matematika. Nilai tes awal (prasiklus) dijadikan bahan untuk mengetahui hasil belajar peserta didik di kelas XI IPA 3 setelah menggunakan Metode sosiodrama sehingga akan tergambarkan hasilnya pada tindakan siklus 1 dan tindakan siklus 2 setelah mengumpulkan dan mengolah data. Berikut ini adalah nilai hasil test pada pra siklus.

\begin{tabular}{|c|c|c|c|c|}
\hline No & Nama & Nilai & Tuntas & Tidak Tuntas \\
\hline 1 & Alfina Damayanti & 60 & & $\sqrt{ }$ \\
\hline 2 & Alfira Supratiwi & 60 & & $\sqrt{ }$ \\
\hline 3 & Aulia Nurul Fitria & 50 & & $\sqrt{ }$ \\
\hline 4 & Bestari Permata Putri & 60 & & $\sqrt{ }$ \\
\hline 5 & Bimma Prastio & 60 & & $\sqrt{ }$ \\
\hline 6 & Cinta Tribuana & 70 & $\sqrt{ }$ & \\
\hline 7 & Diny Nurhayati & 50 & & $\sqrt{ }$ \\
\hline 8 & Dwi Pratiwi & 80 & $\sqrt{ }$ & \\
\hline 9 & Ersa Febriyanah & 60 & & $\sqrt{ }$ \\
\hline 10 & Fira Juniar & 60 & & $\sqrt{ }$ \\
\hline 11 & Firmansyah Perkasa & 50 & & $\sqrt{ }$ \\
\hline 12 & Fredercik Rafili Valdo & 70 & $\sqrt{ }$ & \\
\hline 13 & Friska Sabrina & 60 & & $\sqrt{ }$ \\
\hline 14 & Hairita Mar'atunnisa & 55 & & $\sqrt{ }$ \\
\hline 15 & Indah Sundari & 60 & & $\sqrt{ }$ \\
\hline 16 & Indra Setia Novanto & 80 & $\sqrt{ }$ & \\
\hline 17 & Inez Fannisa Ayudia & 80 & $\sqrt{ }$ & \\
\hline 18 & Isnaeni Aulia Sari & 60 & & $\sqrt{ }$ \\
\hline 19 & M. Haiqal Nabawi Tatudaat & 60 & & $\sqrt{ }$ \\
\hline
\end{tabular}


Edu Cendikia: Jurnal Ilmiah Kependidikan

Volume: 1 | Nomor 3 | Desember 2021 | E-ISSN: 2798-365X | DOI: 10.47709/educendikia.v1i3.1175

\begin{tabular}{|c|c|c|c|c|}
\hline No & Nama & Nilai & Tuntas & Tidak Tuntas \\
\hline 20 & Mahendra Pratama Putra & 70 & $\sqrt{ }$ & \\
\hline 21 & Mahfud Udiarta & 60 & & $\sqrt{ }$ \\
\hline 22 & Mas Djati Winarah & 70 & $\sqrt{ }$ & \\
\hline 23 & Muhamad Ryvaldi & 60 & & $\sqrt{ }$ \\
\hline 24 & Muhammad Alfian Permana & 60 & & $\sqrt{ }$ \\
\hline 25 & Muhammad Daffa Nugroho & 50 & & $\sqrt{ }$ \\
\hline 26 & Muhammad Fudolli & 70 & $\sqrt{ }$ & \\
\hline 27 & Muhammad Reza Khatami & 50 & & $\sqrt{ }$ \\
\hline 28 & Mutia Miranda & 60 & & $\sqrt{ }$ \\
\hline 29 & Putri Maemunah Harisbaya & 70 & $\sqrt{ }$ & \\
\hline 30 & Putri Oktaviani & 80 & $\sqrt{ }$ & \\
\hline 31 & Revianne Putri Widyanti & 60 & & $\sqrt{ }$ \\
\hline 32 & Sintia & 60 & & $\sqrt{ }$ \\
\hline 33 & Syahrul Maulana & 60 & & $\sqrt{ }$ \\
\hline 34 & Syam Alpin Akbar & 60 & & $\sqrt{ }$ \\
\hline 35 & T. Adam Juliansyah & 50 & & \\
\hline 36 & Tsurayya Ghaisani Nur $\mathrm{S}$ & 65 & & \\
\hline 37 & Ummu Hanifah Nafizatul M & 75 & $\sqrt{ }$ & \\
\hline 38 & Vebian Revi Pradana & 75 & $\sqrt{ }$ & \\
\hline 39 & Victor Benaya Larosa & 60 & & \\
\hline 40 & Yeti Susilawati & 65 & & \\
\hline \multicolumn{2}{|c|}{ Rata-rata } & 62,87 & & \\
\hline \multirow{2}{*}{\multicolumn{2}{|c|}{ Nilai Terendah }} & 50 & & \\
\hline & Nilai Tertinggi & 80 & & \\
\hline \multicolumn{2}{|c|}{ Jumlah yang Sudah Tuntas } & 12 & & \\
\hline \multirow{2}{*}{\multicolumn{2}{|c|}{ Jumlah yang Belum Tuntas }} & 28 & & \\
\hline & & $35 \%$ & & \\
\hline
\end{tabular}

Hasil Nilai Test Pra Siklus

Jika di gambarkan dalam grafik data hasil belajar pra siklus seperti pada grafik dibawah ini.

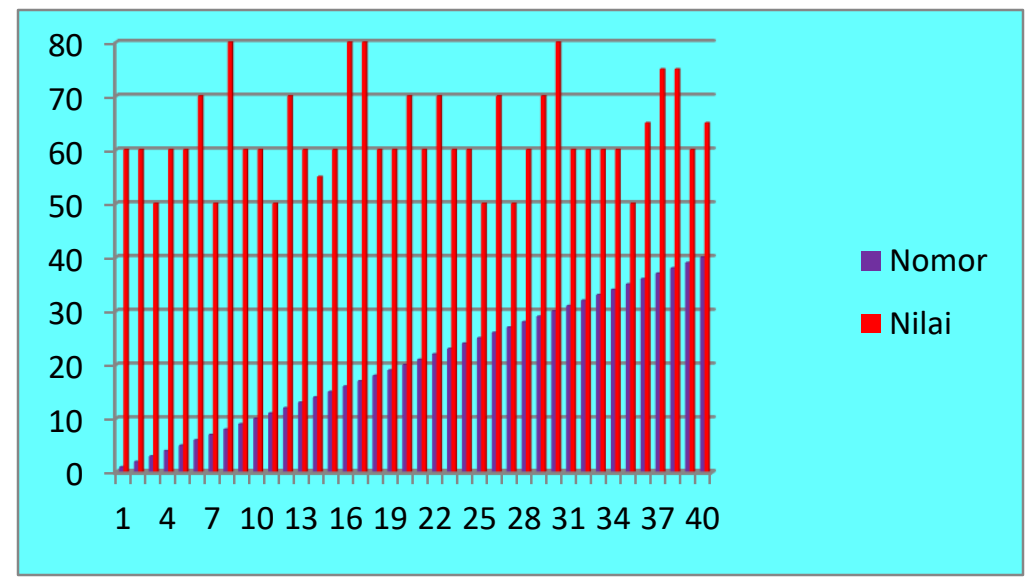


Edu Cendikia: Jurnal Ilmiah Kependidikan

Volume: 1 | Nomor 3 | Desember 2021 | E-ISSN: 2798-365X | DOI: 10.47709/educendikia.vli3.1175

Dari data di atas diketahui hasil rata-rata kelas pelajaran Matematika (pra siklus) yang dilaksanakan masih jauh dari yang diharapkan peserta didik hanya memperoleh nilai rata-rata 62,87 dengan nilai tertinggi 80 dan nilai terendah 50 atau yang sudah memenuhi KKM sebanyak 12 orang yaitu $30 \%$ sedangkan yang belum memenuhi KKM sebanyak 28 orang atau sekitar 70\% dan nilai KKM yang ditentukan adalah 70 . Hal inilah yang menjadi fokus penelitian yang dilaksanakan dalam dua tahap perbaikan pembelajaran. Dari hasil identifikasi masalah diketahui penggunaan metode belajar masih kurang, guru terlalu mendominasi kelas.

\section{Pembahasan}

Dari hasil proses pembelajaran menggunakan metode Inkuiri dan hasil jawaban soal-soal evaluasi dan tugas yang diberikan, kemudian peneliti menggunakan jawaban-jawaban tersebut untuk mengetahui apakah pembelajaran Menjelaskan Pentingnya Kehidupan Demokrasi Dalam Bermasyarakat, Berbangsa Dan Bernegara menggunakan metode Inkuiri tersebut dapat meningkatkan hasil belajar kelas XI IPA 3 SMA Negeri 1 Tajurhalang Kabupaten Bogor. Berikut ini data yang diproleh dari hasil pra siklus, siklus I dan siklus II.

Nilai Pra siklus, Siklus I dan Siklus II

\begin{tabular}{|c|l|c|c|c|}
\hline No & \multicolumn{1}{|c|}{ Nama } & Pra Siklus & Siklus I & Siklus II \\
\hline 1 & Alfina Damayanti & 60 & 65 & 70 \\
\hline 2 & Alfira Supratiwi & 60 & 70 & 75 \\
\hline 3 & Aulia Nurul Fitria & 50 & 60 & 70 \\
\hline 4 & Bestari Permata Putri & 60 & 70 & 80 \\
\hline 5 & Bimma Prastio & 60 & 70 & 75 \\
\hline 6 & Cinta Tribuana & 70 & 80 & 85 \\
\hline 7 & Diny Nurhayati & 50 & 60 & 70 \\
\hline 8 & Dwi Pratiwi & 80 & 90 & 100 \\
\hline 9 & Ersa Febriyanah & 60 & 65 & 70 \\
\hline 10 & Fira Juniar & 50 & 70 & 75 \\
\hline 11 & Firmansyah Perkasa & 70 & 75 & 80 \\
\hline 12 & Fredercik Rafili Valdo & 60 & 70 & 80 \\
\hline 13 & Friska Sabrina & 55 & 65 & 75 \\
\hline 14 & Hairita Mar'atunnisa & 60 & 70 & 75 \\
\hline 15 & Indah Sundari & 80 & 90 & 100 \\
\hline 16 & Indra Setia Novanto & 90 & 95 \\
\hline 17 & Inez Fannisa Ayudia & 70 & 75 \\
\hline 18 & Isnaeni Aulia Sari & 65 & 70 \\
\hline 19 & M. Haiqal Nabawi Tatudaat & 60 & & 70 \\
\hline & & 60 & 60 & \\
\hline
\end{tabular}


Edu Cendikia: Jurnal Ilmiah Kependidikan

Volume: 1 | Nomor 3 | Desember 2021 | E-ISSN: 2798-365X | DOI: 10.47709/educendikia.v1i3.1175

\begin{tabular}{|c|c|c|c|c|}
\hline No & Nama & Pra Siklus & Siklus I & Siklus II \\
\hline 20 & Mahendra Pratama Putra & 70 & 75 & 80 \\
\hline 21 & Mahfud Udiarta & 60 & 70 & 75 \\
\hline 22 & Mas Djati Winarah & 70 & 75 & 80 \\
\hline 23 & Muhamad Ryvaldi & 60 & 70 & 75 \\
\hline 24 & Muhammad Alfian Permana & 60 & 70 & 75 \\
\hline 25 & Muhammad Daffa Nugroho & 50 & 60 & 70 \\
\hline 26 & Muhammad Fudolli & 70 & 80 & 90 \\
\hline 27 & Muhammad Reza Khatami & 50 & 60 & 70 \\
\hline 28 & Mutia Miranda & 60 & 70 & 75 \\
\hline 29 & Putri Maemunah Harisbaya & 70 & 75 & 80 \\
\hline 30 & Putri Oktaviani & 80 & 90 & 95 \\
\hline 31 & Revianne Putri Widyanti & 60 & 65 & 70 \\
\hline 32 & Sintia & 60 & 70 & 75 \\
\hline 33 & Syahrul Maulana & 60 & 70 & 80 \\
\hline 34 & Syam Alpin Akbar & 60 & 70 & 75 \\
\hline 35 & T. Adam Juliansyah & 50 & 60 & 70 \\
\hline 36 & Tsurayya Ghaisani Nur S & 65 & 70 & 75 \\
\hline 37 & Ummu Hanifah Nafizatul M & 75 & 80 & 90 \\
\hline 38 & Vebian Revi Pradana & 75 & 80 & 85 \\
\hline 39 & Victor Benaya Larosa & 60 & 65 & 70 \\
\hline 40 & Yeti Susilawati & 65 & 70 & 80 \\
\hline \multicolumn{2}{|c|}{ Rata-rata } & 62,87 & 71,25 & 78,12 \\
\hline \multicolumn{2}{|c|}{ Nilai Terendah } & 50 & 60 & 70 \\
\hline \multicolumn{2}{|c|}{ Nilai Tertinggi } & 80 & 90 & 100 \\
\hline \multicolumn{2}{|c|}{ Jumlah yang Sudah Tuntas } & 12 & 28 & 40 \\
\hline \multicolumn{2}{|c|}{ Jumlah yang Belum Tuntas } & 28 & 12 & 0 \\
\hline \multicolumn{2}{|c|}{ Prosentase Ketuntasan } & $35 \%$ & $70 \%$ & $100 \%$ \\
\hline
\end{tabular}

Berdasarkan hasil penelitian selama 2 siklus yang bertujuan untuk meningkatkan hasil belajar peserta didik tentang Logika Matematika terlihat pada pelaksanaan siklus I dan II telah menunjukan adanya peningkatan pada proses pembelajaran dengan menggunakan metode sosiodrama interaksi peserta didik dan guru diawali dengan proses pembelajaran dimulai dengan bertanya jawab dan diskusi kelompok. Kemudian ketika proses pembelajaran berlangsung, guru mengelola kelas secara interaktif, membimbing peserta didik 
dan memotivasinya untuk berperan aktif dalam kegiatan pembelajaran. Pada akhir pembelajaran, guru bersama peserta didik menyimpulkan materi pembelajaran yang telah dipelajarinya. Dan kegiatan terakhir guru mengevaluasi peserta didik dengan memberikan soal-soal yang sesuai dengan materi pembelajaran. Berdasarkan hal tersebut dapat di simpulkan bahwa telah ada peningkatan pembelajaran aktivitas peserta didik pada pelajaran Matematika tentang Logika Matematika. Hal ini dapat di lihat dari peningkatan ratarata hasil pencapaian KKM dari pra siklus, siklus I, siklus II yang tergambar pada grafik di bawah ini:

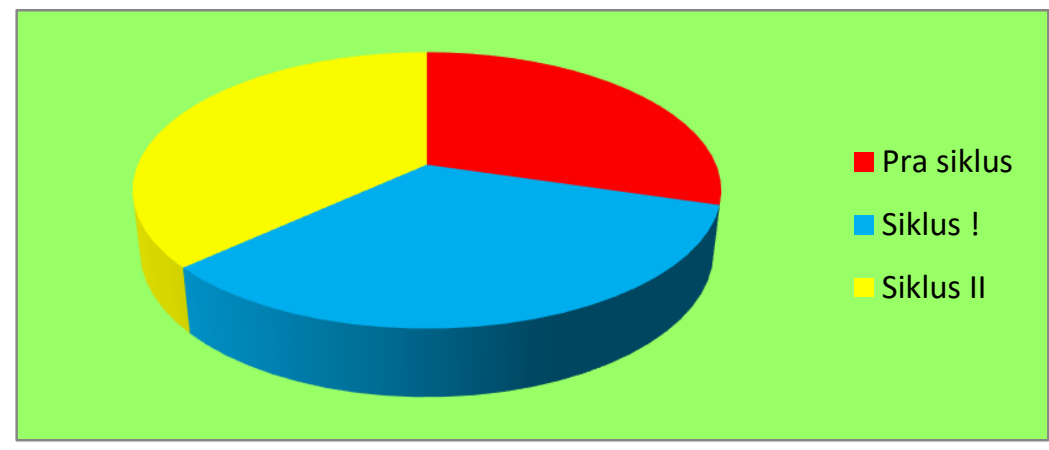

hasil dari pra siklus, siklus I, siklus II

Berdasarkan grafik rekapitulasi presentase pencapaian KKM, nampak terlihat jelas pada saat pra siklus rata kelas hanya 62,87 maka pada siklus I meningkat menjadi 71,25 dan pada siklus II meningkat menjadi 78,12. Fakta ini menunjukan bahwa penerapan metode sosiodrama pada proses pembelajaran di siklus I dan siklus II mampu meningkatkan hasil belajar peserta didik pada pelajaran Matematika tentang Logika Matematika

Peningkatan rata-rata nilai peserta didik juga ditunjang oleh peningkatan nilai terendah dan nilai tertinggi peserta didik setiap siklus seperti yang tergambar pada grafik 4.9 berikut.

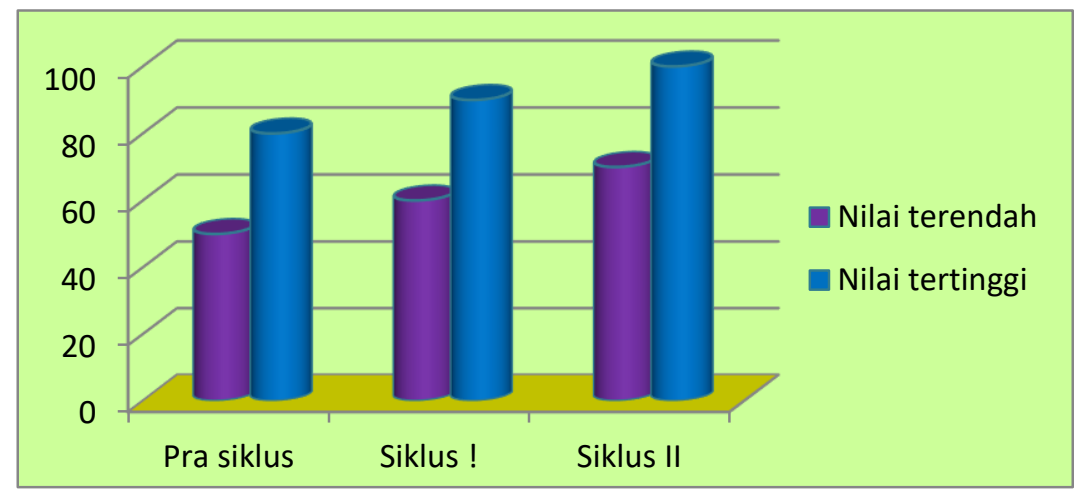

Peningkatan Nilai Tertendah dan Tertinggi Tiap Siklus

Dari grafik 4.9 di atas diperoleh bahwa nilai terendah pada pra siklus adalah 50 kemudian meningkat menjadi 60 pada siklus I dan meningkat lagi menjadi 70 pada siklus II. Selanjutnya nilai tertinggi pada pra siklus adalah 80 kemudian meningkat menjadi 90 pada siklus I dan meningkat lagi menjadi 100 pada siklus II. Hal ini membuktikan bahwa metode sosiodrama cocok untuk diterapkan pada materi Logika Matematika.

Selain peningkatan rata-rata nilai peserta didik, penerapan metode sosiodrama juga dapat meningkatkan persentase ketuntasan belajar peserta didik seperti yang tersaji pada grafik berikut 


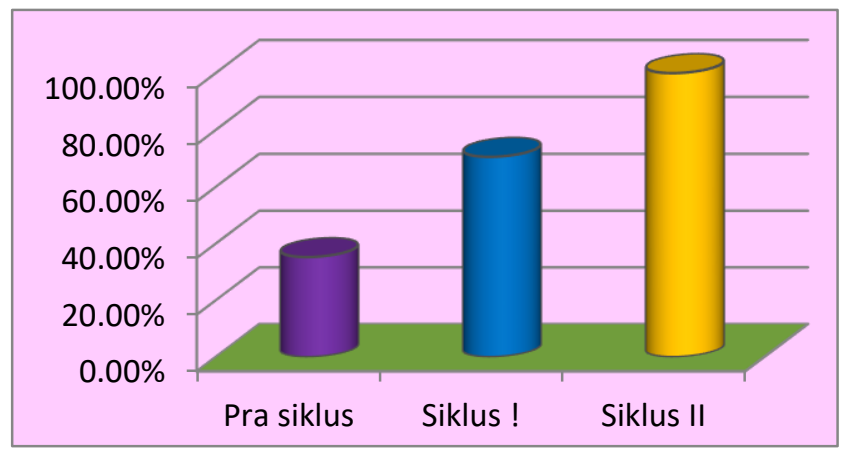

Peningkatan Ketuntasan Belajar Peserta didik Tiap Siklus

Dari grafik 4.10 di atas diperoleh bahwa pada pra siklus hanya $35 \%$ atau 12 peserta didik yang nilainya di atas KKM yang ditetapkan, kemudian pada siklus I meningkat menjadi $70 \%$ atau 28 peserta didik yang nilainya di atas KKM selanjutnya pada siklus II menjadi 100,00\% atau 40 peserta didik yang nilainya di atas KKM.

Data keaktifan peserta didik menunjukkan bahwa pada siklus I 67,5\% atau 27 peserta didik yang aktif, $22,5 \%$ peserta didik cukup aktif atau 9 peserta didik dan yang kurang aktif pada saat pembelajaran $10 \%$ atau 4 peserta didik. Setelah guru memperbaiki hasil refleksi pada siklus I maka pada siklus II didapat $87,5 \%$ atau 35 orang peserta didik yang aktif pada saat pembelajaran dan 12,5\% atau 5 orang peserta didik yang cukup aktif pada saat pembelajaran serta $0,00 \%$ atau tidak ada peserta didik yang tidak aktif pada saat pembelajaran. Dengan banyaknya peserta didik yang aktif pada saat pembelajaran menunjukkan bahwa guru saat menerapkan materi dengan menggunakan metode sosiodrama sudah berhasil melibatkan peserta didik dalam pembelajaran.

Data aktivitas guru menunjukkan bahwa pada siklus I secara umum sudah baik, namun ada beberapa komponen penilaian dari observer yang masih kurang yaitu kemampuan pengelolaan waktu yang kurang optimal dan kurang memotivasi peserta didik sehingga semangat peserta didik pada siklus I secara umum masih kurang. Kekurangan-kekurangan pada siklus I ini kemudian diperbaiki pada siklus II dan aktivitas guru pada siklus II ini secara umum sudah baik.

Peningkatan hasil belajar yang signifikan antara sebelum dan sesudah kegiatan belajar mengajar dengan menggunakan metode sosiodrama disebabkan karena materi Logika Matematika peserta didik dapat bekerja kelompok dan memberikan pendapatnya secara langsung maupun tidak langsung dalam KBM, dan peserta didik mampu memecahkan soal yang diberikan guru secara bersama-sama.

\section{Kesimpulan}

Berdasarkan Penelitian Tindakan Kelas (PTK) yang dilaksanakan maka dapat disimpulkan peserta didik lebih aktif saat pembelajaran mata pelajaran Matematika tentang Logika Matematika. Dari hasil penelitian perbaikan pembelajaran yang dilakukan peneliti dapat menarik kesimpulan sebagai berikut bahwa:

a. Adanya peningkatan hasil belajar peserta didik pada materi Logika Matematika di kelas XI IPA 3 SMAN 34 Pondok Labu Jakartadengan menggunakan metode sosiodrama

b. Penggunaan metode sosiodrama dalam pembelajaran membuat peserta didik tidak bosan dan jenuh sebaliknya merasa senang sehingga aktivitas belajar mereka meningkat. Hal ini terbukti pada siklus I 67,5\% atau 27 peserta didik yang aktif, 22,5\% peserta didik cukup aktif atau 9 peserta didik dan yang kurang aktif pada saat pembelajaran 10\% atau 4 peserta didik. Setelah guru 
memperbaiki hasil refleksi pada siklus I maka pada siklus II didapat 87,5\% atau 35 orang peserta didik yang aktif pada saat pembelajaran dan $12,5 \%$ atau 5 orang peserta didik yang cukup aktif pada saat pembelajaran serta $0,00 \%$ atau tidak ada peserta didik yang tidak aktif pada saat pembelajaran Hal tersebut berpengaruh terhadap hasil belajar yang dicapai peserta didik.

c. Hasil belajar mata pelajaran Matematika khususnya Logika Matematika di kelas XI IPA 3 SMAN 34 Pondok Labu Jakartasebelum menggunakan metode sosiodrama mempunyai nilai rata-rata 62,87. Pada saat pembelajaran diubah menggunakan metode sosiodrama rata-rata hasil belajar peserta didik meningkat menjadi 71,25 pada siklus I dan 78,12 pada siklus II.

\section{Referensi}

Ariani, Nita, dkk. 2010. Meningkatkan Mutu Pendidik dalam Pembelajaran Aljabar. Jakarta: Multazam Mulia Utama.

Djamarah, dkk. 2006. Strategi Belajar Mengajar. Jakarta: Rineka Cipta.

Hamalik, Oemar. 2001. Proses Belajar Mengajar. Jakarta: Bumi Aksara.

Meisera, Lely. 2013. Perbandingan Model Pembelajaran Role Playing dan Pembelajaran Make A Match terhadap Prestasi Belajar Siswa. Bangkalan: STKIP PGRI Bangkalan.

Muhsetyo, Gatot. 2009. Pembelajaran Matematika SD. Jakarta: Universitas Terbuka.

Rusman. 2012. Model-Model Pembelajaran: Mengembangkan Profesionalisme Guru. Depok: PT Raja Grafindo Persada

Sofiraeni, Hj. Renny. 2004. Model-Model Pembelajaran. Bandung: LPMP.

Sutarto Dkk, 2013, Kurikulum dan Pembelajaran, Jakarta, CV. Kemilau Ilmu Semesta

Wahyudin, H. Dinn, dkk. 2007. Pengantar Pendidikan. Jakarta: Universitas Terbuka.

Wahyuni, Okta Rina. 2014. Upaya Peningkatan Prestasi Belajar Siswa Pada Kompetensi Dasar Aritmatika Sosial Dengan Model Pembelajaran Bermain Peran. Pedagogia, Vol. 3, No. 2.

Winkel, 2008, Psikologi Pengajaran, Jakarta, Gramedia Pustaka Tama

Wiryawan dan Nur Hadi, 2000, Strategi Belajar Mengajar, Jakarta, Universitas Terbuka

Ynilita, Erma. 2020. Penerapan Pendekatan Realistic Mathematics Education Untuk Meningkatkan Hasil Belajar Matematika Pada Siswa Kelas III.B Madrasah Ibtidaiyah Negeri Tembilahan Kecamatan Tembilahan. J. Mitra PGMI, Vol. 6, No. 1.

Zaenal Aqib, 2014, Kumpulan Metode Pembelajaran, Bandung, Sanunusa 